\title{
TEKNIK OBSERVASI LINGKUNGAN BERBASIS KEARIFAN LOKAL DALAM MENINGKATKAN KEMAMPUAN BERPIKIR KRITIS
}

\author{
Indriyana Uli ${ }^{1}$, Lizawati ${ }^{2}$ \\ IKIP PGRI Pontianak ${ }^{1,2}$ \\ Posel: iyanauli@gmail.com; lizaucu@gmail.com
}

\begin{abstract}
This research is the application of local kearipan-based environmental observation techniques in improving the critical thinking skills of IKIP PGRI Pontianak students. Based on the objectives of the research, the method to be implemented is using a learning strategy with local kearipan based environmental observation techniques with a qualitative descriptive method in the form of Classroom Action Research. The results showed that the study of old literature with observation techniques based on local wisdom can improve critical thinking of class B students in the morning of semester IV at IKIP PGRI Pontianak. This is indicated by the initial condition of only $68.75 \%$ of students who get completeness, then it increases in cycle I to $75 \%$ and increases again in cycle II to $90 \%$. Based on the increase in the average value and the percentage of students completeness shows that environmental observation techniques based on local wisdom can improve the critical thinking of IKIP PGRI Pontianak students.
\end{abstract}

Keywords: Application; Observation; Environment; Thinking; Critical.

\begin{abstract}
Abstrak
Penelitian ini merupakan penerapan teknik observasi lingkungan berbasis kearipan lokal dalam meningkatkan kemampuan berpikir kritis mahasiswa IKIP PGRI Pontianak. Berdasarkan tujuan penelitian tersebut maka metode yang akan dilaksanakan yaitu mengunakan strategi pembelajaran dengan teknik observasi lingkungan berbasis kearipan lokal dengan metode deskriptif kualitatif dalam bentuk Penelitian Tindakan Kelas. Hasil penelitian menunjukkan bahwa pembelajaran sastra lama dengan teknik observasi lingkungan berbasis kearifan lokal dapat meningkatkan berpikir kritis mahasiswa kelas B pagi semester IV di IKIP PGRI Pontianak. Hal ini ditandai dengan kondisi awal hanya sebanyak $68,75 \%$ mahasiswa yang memperoleh nilai ketuntasan, lalu meningkat pada siklus I menjadi $75 \%$ dan meningkat lagi pada siklus II menjadi 90\%. Berdasarkan peningkatan rata-rata nilai dan presentase ketuntasan siswa tersebut menunjukkan bahwa teknik observasi lingkungan berbasis kearifan lokal dapat meningkatkan berpikir kritis mahasiswa IKIP PGRI Pontianak.
\end{abstract}

Kata kunci: Penerapan; Observasi; Lingkungan; Berpikir; Kritis.

\section{PENDAHULUAN}

Meningkatkan berpikir kritis mahasiswa membutuhkan peranan penguasaan yang lebih dalam proses pembelajaran. Penguasaan tersebut dapat diperoleh dari adanya pengamatan. Untuk meningkatkan berpikir kritis mahasiswa dalam proses pembelajaran. Melalui teknik observasi lingkungan berbasis kearipan lokal diharapkan mampu mengeksplorasi kemampuan berpikir kritis mahasiswa IKIP PGRI Pontianak akan pembelajaran yang memiliki nilai kemanusiaan, adat istiadat, agama, kebudayaan, dan sebagainya.

Teknik observasi lingkungan berbasis kearipan lokal akan memberikan berbagai bentuk pemikiran yang merangsang kreatifitas pelajar. Oleh karena itu, Teknik observasi lingkungan berbasis kearipan lokal mampu memberikan emosional dan pengalaman intelektual yang tinggi sehingga akan memanusiakan manusia. Masyarakat Pontianak yang multietnik kaya budaya dan kearifan lokalnya. Kekayaan Budaya dan kearifan lokal yang beragam memiliki nilai fungsional bagi seluruh kehidupan individu maupun kelompok 
masyarakat. Namun kekayaan potensi dan kaifan lokal tersebut tidak dimanfaatkan secara maksimal apa lagi dalam dunia pendidikan. Lizawati (2019:27) mengungkapkan bahwa pembelajaran yang dilakukan guru cenderung membuat siswa tidak mandiri. Karena siswa hanya memperhatikan penjelasan guru, mengikuti cara penyelesaian soal yang dicontohkan guru, dan menjalankan tugas yang diberikan guru. Hal tersebut juga telihat dari keadaan Insitusi perguruan tinggi yang berjalan hanya pada jalur kurikulum nasional dan melupakan kearifan lokal bangsa Indonesia. Bahkan, ironisnya banyak perguruan tinggi terutama IKIP PGRI Pontianak belum mengembangkan pembelajaran yang berbasis potensi kearifan lokal. Hal ini juga terihat dari berbagai karya ilmiah mahasiswa yang kurang menggali keberagaman kearifan lokal daerahnya. Padahal hampir seluruh mahasiswa IKIP PGRI Pontianak khususnya Program Studi Bahasa dan Sastra Indonesia berasal dari etnik yang berbeda dan tinggal diberbagai daerah pelosok Kalimantan Barat.

Penelitian ini bertujuan agar IKIP PGRI Pontianak memiliki strategi pembelajaran yang berbeda dan dapat menghasilkan model pembelajaran yang lain dari yang sebelumnya. Jika sebelumnya pembelajaran masih bersifat konvensional, maka dengan adanya penelitian ini diharapkan mahasiswa IKIP PGRI Pontianak memiliki karakter diri dan prestasi akademis dan nonakademis dalam melaksanakan hak dan kewajibannya terhadap diri sendiri, masyarakat, dan Tuhan Yang Maha Esa. Berdasarkan pemaparan di atas maka fokus dalam penelitian ini berupa Penerapan Teknik Observasi Lingkungan Berbasis Kearipan Lokal dalam Meningkatkan Kemampuan Berpikir Kritis Mahasiswa IKIP PGRI Pontianak. Dengan rumusan masalah yakni (1) Bagaimanakah pelaksanaan penerapan teknik observasi lingkungan berbasis kearipan lokal dalam meningkatkan kemampuan berpikir kritis mahasiswa IKIP PGRI Pontianak?, (2) Bagaimanakah hasil penerapan teknik observasi lingkungan berbasis kearipan lokal dalam meningkatkan kemampuan berpikir kritis mahasiswa IKIP PGRI Pontianak?. Tujuan penelitian ini mendeskripsikan pelaksanaan penerapan teknik observasi lingkungan berbasis kearipan lokal dalam meningkatkan kemampuan berpikir kritis mahasiswa IKIP PGRI Pontianak dan mendeskripsikan penerapan teknik observasi lingkungan berbasis kearipan lokal dalam meningkatkan kemampuan berpikir kritis mahasiswa IKIP PGRI Pontianak.

Adapun urgensi penting dalam penelitian ini berupa (1) menghasilkan strategi pembelajaran berupa teknik observasi lingkungan berbasis kearipan lokal untuk meningkatkan kemampuan berpikir kritis mahasiswa IKIP PGRI Pontianak. (2) memiliki produk yang menghasilkan buku ajar pembelajaran teknik observasi lingkungan berbasis kearipan lokal untuk meningkatkan kemampuan berpikir kritis mahasiswa IKIP PGRI Pontianak.

Penelitian yang berkaitan dengan berpikir kritis pernah diteliti Mustofa Kamal, Sunoto, dan Indra Suherjanto Imam Suyitno, dengan judul Teknik Pembelajaran Observasi Lingkungan. Reza Rachmadtullah, dengan judul Kemampuan Berpikir Kritis Dan Konsep Diri Dengan Hasil. Surti Rahayu, dengan judul Peningkatan Kemampuan Berpikir Kritis Melalui.

Berdasarkan tiga jurnal yang telah dipaparkan dia atas menunjukkan begitu pentingnya teknik observasi lingkungan berbasis kearifan lokal dalam pembelajaran sastra untuk meningkatkan berpikir kritis di IKIP PGRI Pontianak. Teknik observasi dalam proses belajar mengajar diartikan sebagai cara mengajarkan materi pelajaran dengan 
mengajak siswa mengamati secara teliti suatu objek yang terdapat dalam suatu lingkungan. Faktor lingkungan menjadi hal yang penting dalam pengembangan kegiatan pembelajaran. Hal ini didasari alasan bahwa dalam melangsungkan kehidupannya, siswa akan selalu bergantung pada lingkungan tempatnya hidup. Lingkungan alam dapat memberikan daya dukung kehidupan

Faktor lingkungan menjadi hal yang penting dalam pengembangan kegiatan pembelajaran. Hal ini didasari alasan bahwa dalam melangsungkan kehidupannya, siswa akan selalu bergantung pada lingkungan tempatnya hidup. Mustofa (2016: 16) mengungkapkan bahwa lingkungan alam dapat memberikan daya dukung kehidupan dalam berbagai bentuk kemungkinan yang dapat dipilih manusia untuk menentukan jalan hidupnya. Hubungan antara lingkungan dengan kegiatan manusia dijembatani oleh hal-hal atau pola-pola kebudayaan yang dimiliki oleh manusia.

Menurut Hasyim (2016:24) menjelaskan bahwa teknik observasi lingkungan berbasis kearifan lokal perlu diperkenalkan dan ditanamkan kepada mahasiswa-mahasiswi guna kemampuan berpikir kritisnya. Aktivitas pembelajaran yang baik perlu dilakukan secara kolaboratif dengan melibatkan masyarakat secara luas. Pihak perguruan tinggi perlu melakukan kerjasama dengan pihak masyarakat dalam mengelola pembelajaran di siswa. Dengan demikian, keterlibatan masyarakat menjadi banyak sehingga dapat memperkaya dan memberikan akses kemudahan yang lebih signifikan dalam menyukseskan proses pebelajaran dan meningkatkan kemampuan berpikir kritis.

Berpikir kritis yaitu memahami makna masalah secara lebih dalam, mempertahankan agar pikiran tetap terbuka terhadap segala pendekatan dan pandangan yang berbeda, dan berpikir secara reflektif dan bukan hanya menerima pertanyaan-pertanyaan dan melaksanakan prosedur-prosedur tanpa pemahaman dan evaluasi yang signifikan (Surti, 2016:29). Komponen dari berpikir kritis adalah mengobservasi, mengidentifikasi pola hubungan sebab-akibat, asumsi, alasan, logika, dan bias, membangun kriteria dan mengklasifikasikan, membandingkan dan membedakan, menginterpretasikan, meringkas, menganalisis, menyintesis, menggeneralisasikan, membuat hipotesis, membedakan data yang relevan dan tidak relevan (Reza, 2015:292).

Meningkatkan kemampuan berpikir kritis pada mahasiswa maka harus melibatkan proses mental, misalnya memperhatikan, mengelompokkan, menyeleksi, memutuskan, dan mengambil kesimpulan. Oleh sebab itu kemampuan berpikir kritis dapat ditngkatkan dengan penerapan teknik observasi lingkungan berbasis kearifan lokal.

\section{METODE PENELITIAN}

Metode yang digunakan dalam penelitian ini adalah metode deskriptif kualitatif dalam bentuk Penelitian Tindakan Kelas (PTK) dengan empat tahapan kegiatan pada setiap siklus yaitu: (1) perencanaan, (2) pelaksanaan, (3) observasi, dan (4) refleksi.. Tindakan yang digunakan pada pembelajaran teknik observasi lingkungan berbasis kearifan lokal dengan menggunakan teori humanistik yaitu: (1) menemukan tujuan pembelajaran, (2) menentukan teori pembelajaran, (3) mengidentifikasi kemampuan awal siswa, (4) mengidentifikasi topiktopik pelajaran yang memungkinkan siswa aktif melibatkan diri dalam belajar, (5) merancang fasilitas belajar seperti lingkungan dan media pembelajaran, dan (6) 
membimbing siswa belajar secara aktif. Variabel bebas dalam penelitian ini adalah pembelajaran dengan teknik observasi lingkungan berbasis pendidikan karakter. Variabel terikat dalam penelitian ini adalah kemampuan berpikir kritis. Teknik pengumpul data dalam penelitian ini adalah teknik pengukuran. Sedangkan alat pengumpul data berupa lembar observasi, tes tertulis, dan catatan lapangan.

\section{HASIL DAN PEMBAHASAN}

\section{Hasil Penelitian.}

a. Deskripsi Kondisis Awal

Tabel 1.1

Kategori Kemampuan berpikir Kritis Mahasiswa Kelas B Pagi Mata Kuliah Sastra Lama

\begin{tabular}{|l|l|l|l|}
\hline Rentang Nilai & Kategori & Jumlah & Presentase (\%) \\
\hline $3,51-4,00$ & SB & 7 & 22.88 \\
\hline $2,51-3,50$ & B & 15 & 45.88 \\
\hline $1,51-2,50$ & C & 14 & 31,24 \\
\hline $1,00-1,50$ & K & 0 & - \\
\hline & & 36 & 100 \\
\hline
\end{tabular}

Berdasarkan hal tersebut, perlu adanya peningkatan kualitas pembelajaran yang dapat meningkatkan kemampuan berpikir kritis mahasiswa. Ada banyak model pembelajaran efektif. Fokus teknik pembelajaran yang diterapkan adalah teknik observasi lingkungan berbasis kearifan lokal. Fokus pendekatan menggunakan teori humanistik yaitu: (1) menemukan tujuan pembelajaran, (2) menentukan teori pembelajaran, (3) mengidentifikasi kemampuan awal siswa, (4) mengidentifikasi topik-topik pelajaran yang memungkinkan siswa aktif melibatkan diri dalam belajar, (5) merancang fasilitas belajar seperti lingkungan dan media pembelajaran, dan (6) membimbing siswa belajar secara aktif.

\section{b. Deskripsi Siklus I}

Keberhasilan pelaksanaan tindakan pada siklus I dapat dilihat dari adanya peningkatan kemampuan berpikir kritis mahasiswa yang terlihat lebih baik dibandingkan dengan kemampuan berpikir kritis mahasiswa sebelum tindakan. Berikut disajikan tabel presentase kemampuan berpikir kritis mahasiswa pada siklus 1

Tabel 1.2.

Persentase Data Hasil Observasi Berdasarkan

Pengamatan Kemampuan Berpikir Kritis pada Siklus I

\begin{tabular}{|l|l|l|}
\hline No & Indikator & Presentase (\%) \\
\hline 1 & $\begin{array}{l}\text { Kemampuan mahasiswa mencari pernyataan yang } \\
\text { jelas dari setiap pertanyaan }\end{array}$ & 100 \\
\hline 2 & Kemampuan mahasiswa mencari alasan & 42,75 \\
\hline 3 & $\begin{array}{l}\text { Mahasiswa berusaha mengetahui informasi dengan } \\
\text { baik }\end{array}$ & 90,41 \\
\hline 4 & $\begin{array}{l}\text { Mahasiswa memperhatikan situasi dan kondisi } \\
\text { secara keseluruhan }\end{array}$ & 70,09 \\
\hline 5 & Mahasiswa bersikap dan berpikir terbuka & 88,94 \\
\hline
\end{tabular}




\begin{tabular}{|l|l|l|}
\hline 6 & $\begin{array}{l}\text { Mahasiswa mengambil posisi ketika ada bukti yang } \\
\text { cukup untuk melakukan sesuatu }\end{array}$ & 52,13 \\
\hline 7 & $\begin{array}{l}\text { Mahasiswa mencari penjelasan sebanyak mungkin } \\
\text { apabila ada kemungkinan }\end{array}$ & 35,72 \\
\hline 8 & $\begin{array}{l}\text { Mahasiswa bersikap secara sistematis dan teratur } \\
\text { dengan bagian-bagian dari keseluruhan masalah }\end{array}$ & 100 \\
\hline
\end{tabular}

Peningkatan kegiatan mahasiswa dalam proses pembelajaran berdampak positif bagi terwujudnya peningkatan kemampuan berpikir kritis mahasiswa. Skor hasil tes mahasiswa pada mata kuliah sastra lama pada siklus I menunjukkan adanya peningkatan. Perhitungan nilai tes mahasiswa dilakukan dengan cara skor yang diperoleh mahasiswa dibagi dengan skor maksimal yaitu 16 dilakukan 4 (empat). Nilai tes mahasiswa ini kemudian digunakan untuk menghitung nilai berpikir kritis.

Tabel 1.3.

Presentase Data Hasil Tes

Berdasarkan Indikator Pengamatan Kemampuan Berpikir Kritis Pada Siklus I

\begin{tabular}{|l|l|l|}
\hline No & Indikator & Presentase (\%) \\
\hline 1 & $\begin{array}{l}\text { Mahasiswa memakai sumber yang memiliki } \\
\text { kredibilitas }\end{array}$ & 100,00 \\
\hline 2 & Mahasiswa berusaha tetap relevan dengan ide utama & 57,59 \\
\hline 3 & $\begin{array}{l}\text { Mahasiswa mengingat kepentingan yang asli dan } \\
\text { mendasar }\end{array}$ & 85,72 \\
\hline 4 & Mahasiswa mencari alternative & 76,34 \\
\hline
\end{tabular}

menjumlahkan nilai tes dengan nilai hasil pengamatan masing-masing mahasiswa. Bobot nilai tes adalah $40 \%$ sedangkan bobot nilai observasi adalah $60 \%$. Berikut ini tabel kriteria nilai kemampuan berpikir kritis mahasiswa pada siklus I.

Tabel 1.4.

Kriteria nilai Kemampuan Berpikir Kritis Mahasiswa Siklus I

\begin{tabular}{|l|l|l|l|}
\hline Rentang Nilai & Kategori & Jumlah & Presentase (\%) \\
\hline $1,00-1,50$ & K & 0 & - \\
\hline $1,51-2,50$ & C & 8 & 26,00 \\
\hline $2,51-3,50$ & B & 19 & 52,13 \\
\hline $3,51-4,00$ & SB & 9 & 21,88 \\
\hline Jumlah & 36 & 100 \\
\hline
\end{tabular}

Berdasarkan nilai kemampuan berpikir kritis yang diperoleh dari lembar pengamatan dan hasil tes tersebut dapat dilihat bahwa kemampuan berpikir kritis mahasiswa masih di bawah kriteria keberhasilan yang diharapkan. Untuk itu perlu ada perbaikan tindakan pada siklus II.

\section{c. Deskripsi Siklus II}

Keberhasilan pelaksanaan tindakan pada siklus II dapat dilihat dari peningkatan kemampuan berpikir kritis mahasiswa yang terlihat lebih baik dibandingkan dengan kemampuan berpikir kritis mahasiswa pada saat sebelum tindakan. Hal ini dapat dilihat dari 
kemampuan berpikir kritis mahasiswa pada pertemuan pertama khususnya pada indikator kemampuan mahasiswa mencari pernyataan yang jelas dari setiap pertanyaan, mahasiswa berusaha mengetahui informasi dengan baik, mahasiswa bersikap dan berpikir terbuka, dan mahasiswa bersikap secara sistematis dan teratur dengan bagian-bagian dari keseluruhan masalah. Berikut presentase kemampuan berpikir kritis mahasiswa pada siklus II.

Tabel 1.5.

Presentase data Hasil Observasi

Berdasarkan Indikator Pengamatan Kemampuan Berpikir Kritis pada Siklus II

\begin{tabular}{|l|l|l|}
\hline No. & Indikator & Presentase (\%) \\
\hline 1 & $\begin{array}{l}\text { Kemampuan mahasiswa mencari pernyataan yang jelas dari } \\
\text { setiap pertanyaan }\end{array}$ & 100 \\
\hline 2 & Kemampuan mahasiswa mencari alasan & 70,88 \\
\hline 3 & Mahasiswa berusaha mengetahui informasi dengan baik & 95,09 \\
\hline 4 & $\begin{array}{l}\text { Mahasiswa memperhatikan situasi dan kondisi secara } \\
\text { keseluruhan }\end{array}$ & 88,50 \\
\hline 5 & Mahasiswa bersikap dan berpikir terbuka & 97,88 \\
\hline 6 & $\begin{array}{l}\text { Mahasiswa mengambil posisi ketika ada bukti yang cukup } \\
\text { untuk melakukan sesuatu }\end{array}$ & $\begin{array}{l}77,13 \\
\text { ada kemungkinan }\end{array}$ \\
\hline 7 & $\begin{array}{l}\text { Mahasiswa bersikap secara sistematis dan teratur dengan } \\
\text { bagian-bagian dari keseluruhan masalah }\end{array}$ & 100 \\
\hline
\end{tabular}

Peningkatan kegiatan mahasiswa dalam proses pembelajaran berdampak positif bagi terwujudnya peningkatan kemampuan berpikir kritis mahasiswa. Skor hasil tes mahasiswa pada mata kuliah sastra lama pada siklus II menunjukkan adanya peningkatan. Perhitungan nilai tes mahasiswa dilakukan dengan cara skor yang diperoleh mahasiswa dibagi dengan skor maksimal yaitu 16 dilakukan 4 (empat). Nilai tes mahasiswa ini kemudian digunakan untuk menghitung nilai berpikir kritis.

Tabel 1.6

Presentase Data Hasil Tes

Berdasarkan Indikator Pengamatan Kemampuan Berpikir Kritis Pada Siklus II

\begin{tabular}{|c|c|c|}
\hline No & Indikator & Presentase $(\%)$ \\
\hline 1 & $\begin{array}{llll}\text { Mahasiswa memakai sumber yang memiliki } \\
\text { kredibilitas }\end{array}$ & 100,00 \\
\hline 2 & Mahasiswa berusaha tetap relevan dengan ide utama & 85,38 \\
\hline 3 & $\begin{array}{l}\text { Mahasiswa mengingat kepentingan yang asli dan } \\
\text { mendasar }\end{array}$ & 91,96 \\
\hline 4 & Mahasiswa mencari alternative & 88,29 \\
\hline
\end{tabular}

Peningkatan indikator kemampuan berpikir kritis mahasiswa berdasarkan pengamatan pada siklus II juga berdampak baik pada skor tes mahasiswa. Data menunjukkan bahwa skor rata-rata tes mahasiswa pada siklus II mengalami peningkatan 
dengan nilai tes mahasiswa pada siklus I. Rata-rata skor tes mahasiswa pada siklus I 80,66\%, sedangkan pada siklus II meningkat menjadi 91,41\%.

Perhitungan nilai kemampuan berpikir kritis mahasiswa dilakukan dengan menjumlahkan nilai tes dengan nilai hasil pengamatan masing-masing mahasiswa. Bobot nilai tes adalah $40 \%$ sedangkan bobot nilai observasi adalah $60 \%$. Berikut ini tabel kriteria nilai kemampuan berpikir kritis mahasiswa pada siklus II.

Tabel 1.7.

Kriteria nilai Kemampuan Berpikir Kritis Mahasiswa Siklus II

\begin{tabular}{|l|l|l|l|}
\hline Rentang Nilai & Kategori & Jumlah & Presentase $(\%)$ \\
\hline $1,00-1,50$ & K & 0 & - \\
\hline $1,51-2,50$ & C & 4 & 12,12 \\
\hline $2,51-3,50$ & B & 10 & 36,36 \\
\hline $3,51-4,00$ & SB & 22 & 51,52 \\
\hline Jumlah & 36 & 100 \\
\hline
\end{tabular}

\section{Pembahasan}

Hasil observasi kemampuan berpikir kritis mahasiswa selama proses pembelajaran juga lebih baik dibandingkan dengan hasil observasi pada siklus I. Berdasarkan hasil refleksi pada siklus II, indikator keberhasilan penelitian ini telah tercapai, sehingga penelitian tindakan kelas dianggap berhasil dan hanya dilaksanakan sampai dengan siklus II. Berdasarkan hasil observasi dan refleksi, kelebihan-kelebihan pelaksanaan pembelajaran pada siklus II menggunakan teknik observasi lingkungan berbasis kearifan lokal adalah kemampuan berpikir kritis mahasiswa mengalami peningkatan. Hal ini dapat dilihat dari jumlah mahasiswa yang memperoleh nilai kemampuan berpikir kritis memenuhi ketuntasan sebanyak $87,50 \%$ dari keseluruhan mahasiswa.

Berikut merupakan grafik peningkatan nilai rata-rata pada siklus dan I siklus II:

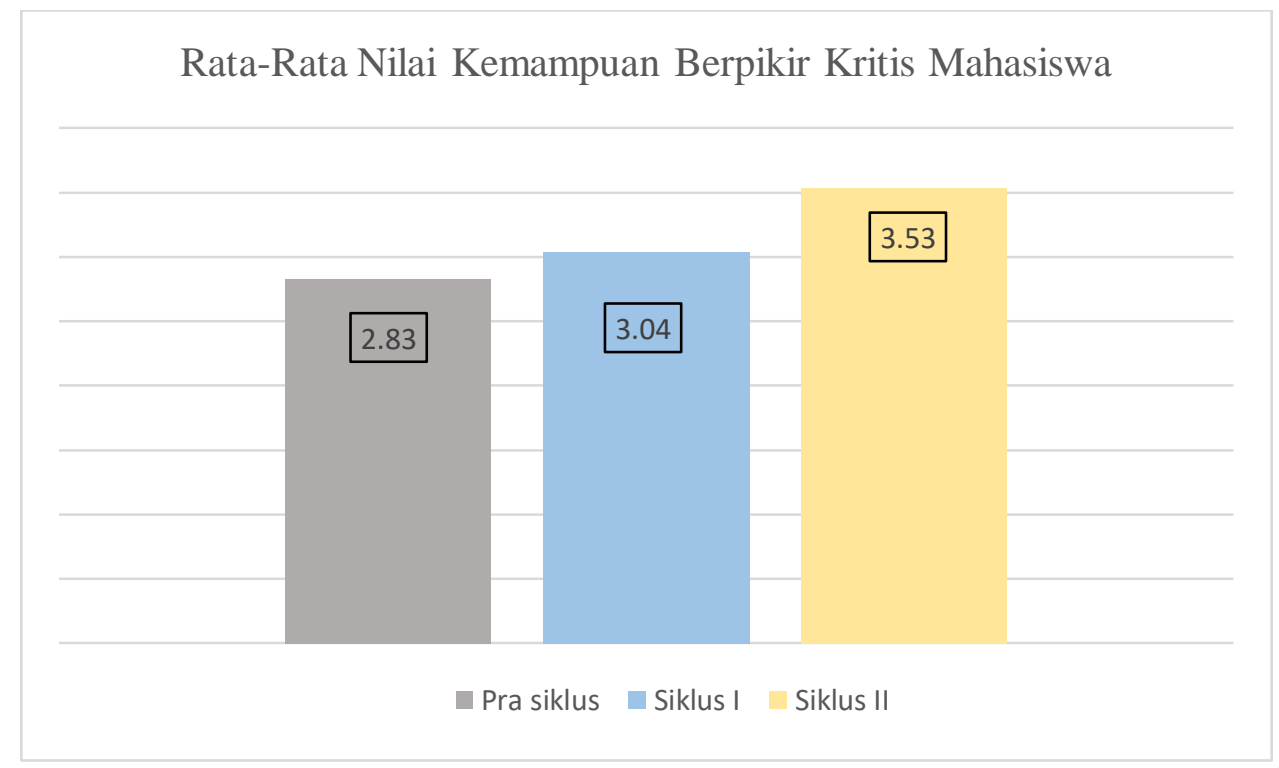

Gambar 5.1 Nilai Rata-Rata Kemampuan Berpikir Kritis Mahasiswa 


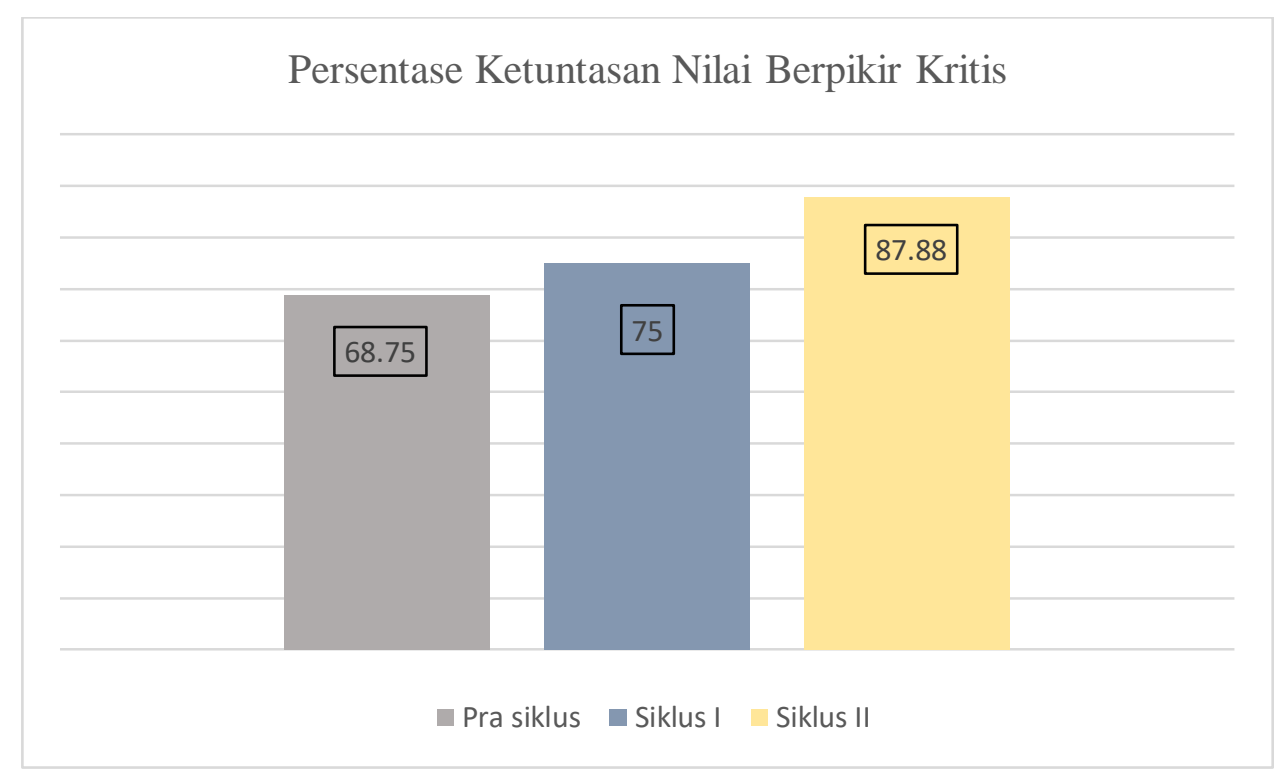

Gambar 1.1 Presentase Nilai Ketuntasan Berpikir Kritis

Hasil penelitian menunjukkan bahwa pembelajaran sastra lama dengan teknik observasi lingkungan berbasis kearifan lokal dapat meningkatkan berpikir kritis mahasiswa kelas B pagi semester IV di IKIP PGRI Pontianak. Hal ini ditandai dengan kondosi awal hanya sebanyak 68,75\% mahasiswa yang memperoleh nilai ketuntasan, lalu meningkat pada siklus I menjadi 75\% dan meningkat lagi pada siklus II menjadi $90 \%$. Berdasarkan peningkatan rata-rata nilai dan presentase ketuntasan siswa tersebut menunjukkan bahwa teknik observasi lingkungan berbasis kearifan lokal dapat meningkatkan berpikir kritis mahasiswa IKIP PGRI Pontianak.

\section{SIMPULAN}

Berdasarkan hasil penelitian dapat disimpulkan bahwa penerapan teknik observasi lingkungan berbasis kearifan lokal dapat meningkatkan kemampuan berpikir kritis mahasiswa IKIP PGRI Pontianak. Hal ini dilihat berdasarkan nilai peningkatan dari hasil analisis lembar observasi berpikir kritis mahasiswa dan hasil tes belajar yang mengalami peningkatan. Hal ini ditandai dengan kondosi awal hanya sebanyak 68,75\% mahasiswa yang memperoleh nilai ketuntasan, lalu meningkat pada siklus I menjadi 75\% dan meningkat lagi pada siklus II menjadi 90\%.Sehingga pada siklus II persentase setiap aspek kemandirian pada hasil angket serta persentase rata-rata kemandiriannya memenuhi indikator keberhasilan.

\section{DAFTAR PUSTAKA}

D. K. Filsaime. 2008. Menguak Rahasia Berpikir Kritis dan Kreatif. Jakarta, Indonesia: Prestasi Pustaka.

Hasyim Hasanah. 2016. Teknik-Teknik Observasi (Sebuah Alternatif Metode Pengumpulan Data Kualitatif Ilmuilmu Sosial). Jurnal at-Taqaddum, 1 (8): 22-46.

Lizawati, Indriyana Uli. 2019. Peningkatan Kemandirian Belajar Melalui Pembelajaran Sastra Nusantara Berbasis Pendidikan Karakter Tanggung Jawab. SeBaSa: Jurnal Pendidikan Bahasa dan Sastra Indonesia, 2 (1): 25-30. 
SeBaSa: Jurnal Pendidikan Bahasa dan Sastra Indonesia

Mustofa Kamal, Sunoto, dan Indra Suherjanto Imam Suyitno. 2015. Teknik Pembelajaran Observasi Lingkungan. Jurnal Kependidikan, 46 (1): 14-28.

Reza Rachmadtullah. 2015. Kemampuan Berpikir Kritis Dan Konsep Diri Dengan Hasil. Jurnal Pendidikan Dasar, 6 (2): 288-298.

Sultan. 2010. Gaya Bahasa Guru dalam Interaksi Pembelajaran. Jurnal Penelitian Pendidikan Insani, 11 (2): 82-89.

Surti Rahayu. 2016. Peningkatan Kemampuan Berpikir Kritis Melalui. Jurnal Penelitian Pendidikan Indonesia, 1 (4): 27-32. 